\title{
Reticulin antibodies in patients with coeliac disease and their relatives
}

\author{
FIONA M. STEVENS, R. LLOYD, BRIDGET EGAN-MITCHELL, M. J. MYLOTTE, \\ P. F. FOTTRELL, R. WRIGHT, B. McNICHOLL, AND C. F. MCCARTHY ${ }^{1}$ \\ From the Departments of Gastroenterology, Paediatrics, and Biochemistry of University College, Galway, \\ and the Regional Hospital, Galway, and Department of Medicine, University of Southampton
}

SUMmARY The sera of 69 index coeliac patients, 121 of their first-degree relatives, and 104 controls were screened for the presence of reticulin antibodies. Among the untreated coeliac patients $75 \%$ of adults and $93 \%$ of children had reticulin antibody in their serum. Reticulin antibody was not present in any adequately treated coeliac patient.

Of the first-degree relatives, 21 were reticulin antibody positive; 17 of these were biopsied and 12 were shown to have coeliac disease. Sixty-five of the coeliac relatives who did not have reticulin antibodies in their sera were biopsied and two had coeliac disease. Of the 68 relatives and 63 controls with normal biopsies, five of the relatives and four of the controls were reticulin antibody positive.

The incidence of coeliac disease in the west of Ireland is about 1 in 450 of the population (Mylotte et al, 1973), and the incidence in first-degree relatives of coeliac patients in the area is $10 \%$ (Mylotte, Egan-Mitchell, McCarthy, and McNicholl, 1973; Mylotte, Egan-Mitchell, Fottrell, McNicholl, and McCarthy, 1972) which is similar to the figure of 10 to $18 \%$ in studies in which intestinal biopsy results are available (MacDonald, Dobbins, and Rubin, 1965; Robinson, Watson, Wyatt, Marks, and Roberts, 1971; Stokes, Asquith, and Cooke, 1973; Shipman, Williams, Kay, and Townley, 1973). If the incidence and behaviour of lymphoma and carcinoma in coeliac patients in Ireland is similar to that reported elsewhere (Gough, Read, and Naish, 1962; Austad, Cornes, Gough, McCarthy, and Read, 1967; Harris, Cooke, Thompson, and Waterhouse, 1967; Barry and Read, 1973; Stokes and Holmes, 1974; Asquith, 1974) the detection and treatment of affected relatives is desirable, not only that the disease may be treated, but also to diagnose, treat and, if possible, prevent the occurrence of tumours.

In 1971 Seah, Fry, Hoffbrand, and Holborow (1971a) described the finding of an IgG class antibody in the serum of patients with dermatitis herpetiformis and adult coeliac disease. Since then, this 'antireticulin antibody', 'basement membrane

${ }^{1}$ Requests for reprints should be sent to C. F. McCarthy at the Regional Hospital.

Received for publication 9 June 1975. antibody' 'reticulin antibody', or 'connective tissue antibody' has been found in the serum of adults and children with coeliac disease in varying frequencies (Amman and Hong, 1971; Seah, Fry, Rossiter, Hoffbrand, and Holborow, 1971b; Alp and Wright, 1971; von Essen, Savilahti, and Pelkonen, 1972; Brown, Ferguson, Carswell, Horne, and MacSween, 1973; Seah, Fry, Holborow, Rossiter, Doe, Magalhaes, and Hoffbrand, 1973; Rizzetto and Doniach, 1973; Magalhaes, Peters, and Doe, 1974).

The purpose of the present study was to determine if coeliac patients in the west of Ireland have the same incidence of reticulin antibody in their sera as have coeliacs in other areas; the relationship of treatment to reticulin status in adults and children with coeliac disease; if the presence of reticulin antibody is an accurate method of detecting relatives who have coeliac disease; if within family units coeliacs are uniformly reticulin antibody positive or negative; and if coeliac relatives who have a normal jejunal biopsy have a higher incidence of positive reticulin antibody than controls.

\section{Materials and Methods}

Sixty-nine coeliac patients whose small intestinal mucosa showed villous atrophy and decreased levels of mucosal enzymes were studied (20 under the age of 12,49 over the age of 12). All patients had shown 
clinical improvement on a gluten-free diet and repeat biopsies in 53 have shown morphological and enzymatic improvement. One hundred and twentyone first-degree relatives were studied and intestinal biopsies were obtained in 82 . Their ages ranged from 5 months to 60 years, and 33 parents, 67 siblings, and 21 children of coeliacs were studied.

Sixty-three biopsied symptomatic controls (ages 980), who were undergoing investigation for anaemia, dyspepsia, diarrhoea and short stature, were studied. Forty-one random control serum samples were obtained from the Clinical Biochemistry Laboratory, Regional Hospital, Galway.

When the coeliac patients, their relatives and symptomatic controls were seen for clinical examination and intestinal biopsy, a serum sample was obtained, coded and stored frozen at $-20^{\circ} \mathrm{C}$ until taken to Southampton for antibody analysis. Small intestinal biopsies were obtained from the distal duodenum or proximal jejunum with the paediatric Crosby capsule or the Watson capsule or from the proximal duodenum with the Olympus duodenoscope (GIF type D2). Part of the biopsy was sealed in parafilm and stored at $-20^{\circ} \mathrm{C}$ until multiple mucosal enzyme assays were performed.

Intraepithelial lymphocytes were counted on 5 or $6 \mu$ thick coded sections of biopsy stained with PAS and counterstained with haematoxylin and tartrazine. The sections were viewed at a magnification of $\times 400$. Cell counts were made along the side of well orientated villi. On most sections at least 1000 enterocytes and only lymphocytes completely above the level of the enterocyte basement membrane were counted. The results are expressed as intraepithelial lymphocytes per 1000 enterocytes.

Reticulin antibodies were sought in serum samples by indirect immunofluorescence using rat kidney, liver and gastric tissue (Seah et al, 1971a), the staining patterns being predominantly $\mathbf{R}_{\mathbf{1}} / \mathbf{R}_{\mathbf{s}}$ with an occasional $\mathbf{R}_{2}$ pattern (Rizzetto and Doniach, 1973). All sera were tested at a dilution of $1 / 10$ using polyvalent fluorescent antihuman globulin.

Mucosal disaccharidase activity was assayed by the method of Dahlqvist (1968); alkaline phosphatase by the microtechnique of Kelly and Hamilton (1970); and protein concentration by the method of Lowry, Rosebrough, Farr, and Randall (1951). Serum immunoglobulins were assayed with Immunoplates (Baxter Hyland). Routine haematological and biochemical investigations were performed using standard laboratory techniques.

\section{Results}

Eighty-three coeliac patients (69 index cases and 14 detected during the study) had their serum analysed for reticulin antibodies. Thirty-six of 48 adults with untreated coeliac disease had positive tests and 14 of 15 children who were untreated were positive. The treated patients studied include some from the preceding untreated group after they had been on strict gluten-free diets for at least three months and repeat biopsy has shown morphological and enzymatic improvement. None of the 30 treated patients (17 adults and 13 children) was reticulin antibody positive.

The presence of reticulin antibody was found to be unrelated to sex or blood group (ABO or Rhesus) of the patients. There is no significant correlation between reticulin status and faecal fats, serum iron or mucosal lymphocyte counts. Serum folate levels were higher in the reticulin antibody-negative group (mean $6.77 \mathrm{ng} / \mathrm{ml}$, SD 6.42) than in the antibodypositive group (mean $3.49 \mathrm{ng} / \mathrm{ml}$, SD 2.57). However, some patients in both groups had been given folate supplements before referral to hospital, thus making difficult the interpretation of this apparently significant difference.

Significantly higher levels of IgG were found in untreated adult coeliac patients with reticulin antibodies in their sera (mean $1364 \mathrm{mg} \%$, SD 394) when compared with patients without antibody (mean $1085 \mathrm{mg} \%$, SD 268, $\mathrm{P}=<0.05$ ). No differences were found in the levels of IgA and IgM between the positive and negative groups.

Twenty-one $(17 \cdot 3 \%)$ of 121 first-degree relatives of index coeliac patients studied have reticulin antibody in a significant titre. Seventeen of these reticulin antibody-positive relatives have had a small intestinal biopsy, but the remaining four, all members of one family, have so far declined further investigation.

Biopsies were obtained in 82 of the first-degree relatives. Villous atrophy and low mucosal enzymes, compatible with coeliac disease, were found in 14 of those biopsied. Twelve of these relatives had reticulin antibodies present in their sera and the remaining two, both women aged over 45 , were reticulin antibody negative. Amongst the group of 68 relatives with morphologically normal biopsies were five $(7.32 \%$ with positive reticulin antibodies. Sera from 104 control subjects were studied and five sera were found to have reticulin antibodies. Four (6.3\%) of 63 symptomatic patients with normal villous morphology were reticulin antibody positive. The other positive sample was from a woman attending the Maternity Department with recurrent macrocytic anaemia of pregnancy. The patient has declined further investigation.

In the table are shown the intraepithelial lymphocytes counts and levels of mucosal enzymes, where available, of the five relatives and four controls with 


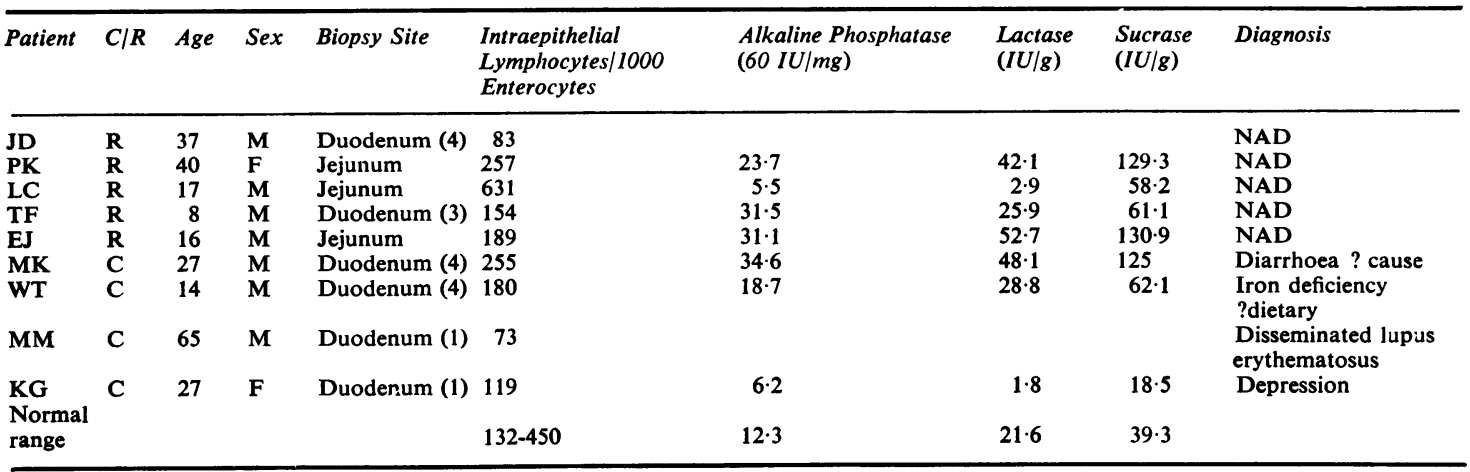

Table Mucosal enzymes and intraepithelial lymphocyte counts in relatives and controls with normal villous morphology and positive reticulin antibodies

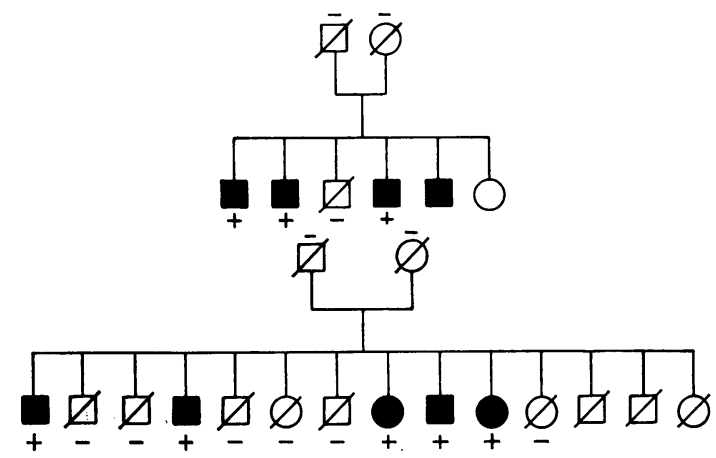

Fig. 1
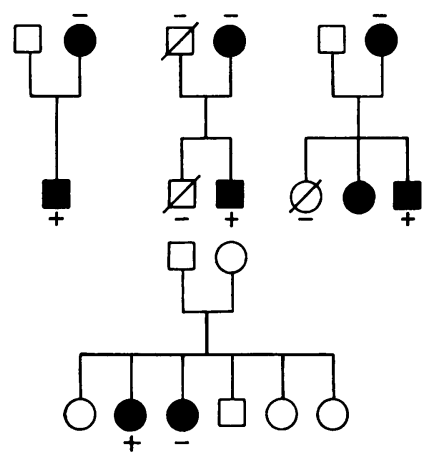

FIG. 2

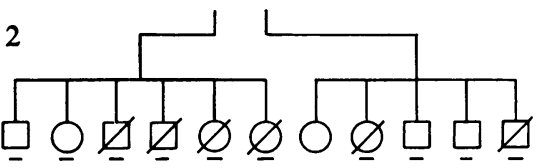

Figs 1 and 2 Reticulin antibodies and coeliac family trees.

Male coeliac; 0 female coeliac; $\square$ or $\varnothing$ male or female relative in whom a normal biopsy has been obtained: $\square$ or $\bigcirc$ male or female relative in whom no biopsy has been obtained.

+ or - above or below symbol indicates the presence or absence of reticulin antibody in serum. (No sign indicates reticulin antibody status not known.) reticulin antibodies and normal villous morphology. LC, the non-identical twin of a coeliac patient has a raised intraepitheliallymphocyte count and depressed mucosal enzyme levels. The results available on the remaining four relatives are within the normal range. The significance of low enzymes in the control KG is not known as the biopsy is from the proximal duodenum and the normal range for this region is still to be determined.

Figure 1 shows the family trees of two families with more than three coeliac siblings. In both families the parents have normal small intestinal biopsies and are reticulin antibody negative. All the coeliac children are reticulin antibody positive and there are no false positives among normal siblings. At the time of study all family members were on a normal gluten-containing diet.

Figure 2 shows four further family trees in which the reticulin status of the two coeliac members of a family are different. Thus the tendency to develop reticulin antibody does not appear to be inherited in the same manner as coeliac disease itself.

\section{Discussion}

Reticulin antibodies have been found in $64 \%$ of 56 adults and $52 \%$ of 27 children with coeliac disease in the west of Ireland. The low incidence of positives in children in the present study is accounted for by the similar numbers of treated and untreated patients. The incidence of $93 \%$ among untreated children, although similar to that found by Seah et al (1971b and 1973), is higher than the $68 \%$ and $67 \%$ found by von Essen et al (1972) and Brown et al (1973) respectively. The higher incidence of positive reticulin antibodies among adults with coeliac disease in the present study may be due to the high proportion of untreated patients in the study. These were newly diagnosed cases, patients not adhering to the gluten-free diet, or patients on gluten 
challenge. However, Seah et al (1973) and Magalhaes et al (1974) found an incidence of about $59 \%$ positive reticulin antibodies in untreated coeliac adults whereas $75 \%$ of the untreated adults with coeliac disease in the west of Ireland are reticulin antibody positive. No explanation has been found for the higher incidence of reticulin antibody in coeliac adults on normal gluten-containing diets found in this study.

Seah et al (1971) and Alp and Wright (1971) noted the relationship of reticulin antibody to the presence of gluten in the diet. The decreased incidence of the antibody on a gluten-free diet has been confirmed by von Essen et al (1972), Seah et al (1973), Magalhaes et al (1974). In our study, strict criteria for treatment were used. Patients were only considered treated if their small intestinal mucosal biopsies showed morphological and enzymatic improvement in association with clinical improvement. When these criteria are employed none of the 30 treated patients were reticulin antibody positive, which is much lower than the $18.6 \%$ of Seah et al (1973) and the $23 \%$ of Magalhaes et al (1974). The disappearance of an antibody on dietary treatment and its reappearance on gluten challenge (Alp and Wright, 1971; von Essen et al, 1972) is unlike the behaviour of the autoantibodies found in 'autoimmune' disease. Rizzetto and Doniach (1973) and Mawhinney (1974), likened this behaviour to that of serum dietary protein antibodies in coeliac disease, which disappears on treatment with a gluten-free diet (Alarcón-Segovia, Herskovic, Wakin, Green, and Scudamore, 1974; Kenrick and Walker-Smith, 1970; Ferguson and Carswell, 1972).

The incidence of positive reticulin antibodies among relatives with morphologically normal biopsies, $7.32 \%$, is similar to the $6.3 \%$ found in biopsied symptomatic controls. These figures are similar to the $5 \%$ found in controls by Rizzetto and Doniach (1973), lower than the $15 \%$ among children found by Brown et al (1973), and higher than the $1.4 \%$ of Seah et al (1973) and the $2.4 \%$ of Magalhaes et al (1974). None of the controls or relatives with morphologically normal small intestinal biopsies was considered to have Crohn's disease in which $25 \%$ of patients are reticulin antibody positive (Alp and Wright, 1971; Seah et al, 1973; Magalhaes et al, 1974). The other conditions giving frequent false positive results, namely, dermatitis herpetiformis (Seah et al, 1971a; Seah et al, 1971b; Seah et al, 1973; Rizzetto and Doniach, 1973), heroin addiction, Sjögren's syndrome and rheumatoid arthritis (Rizzetto and Doniach, 1973), and IgA deficiency (Amman and Hong, 1971; von Essen et $e l, 1972)$ were not found in any of the relatives or controls. Brown et al (1973) found a high percentage of false positives in children and suggested that the disease process in these patients was associated with gastrointestinal damage, although no increased incidence had been found in children with villous atrophy due to intolerance of cow's milk (von Essen et al, 1972) or in tropical sprue (Seah et al, 1973). Gastroenteritis may have been present in control MK.

Raised intraepithelial lymphocyte counts have been found in untreated coeliac disease (Ferguson and Murray, 1971; Fry, Seah, McMinn, and Hoffbrand, 1972; Holmes, Asquith, Stokes, and Cooke, 1974; Montgomery and Shearer, 1974; Ferguson, Asquith, and Cooke, 1974) and in postinfective diarrhoea and tropical sprue (Montgomery and Shearer, 1974). Fry et al (1972) considered the finding of increased lymphocytic infiltration of the intestinal epithelium of patients with dermatitis herpetiformis to be a far more sensitive indication and early sign of gluten sensitivity than the abnormal macroscopic mucosal appearance. Nusslé, Frei, Bozic, and Gautier (1970), during a study of proximal and distal biopsies from the small intestine of untreated coeliac patients, showed that decreased mucosal enzymes were a more constant finding than morphological abnormality in the distal biopsy. McNicholl, Egan-Mitchell, and Fottrell (1974) have shown that in the small intestinal mucosa of coeliac children on gluten trial, a relapse in enzymatic activity may occur many months before villous atrophy reappears.

It would appear that decreased mucosal enzyme activity and raised intraepithelial lymphocyte counts are more critical indicators of gluten sensitivity than are the morphological criteria usually employed in the diagnosis of coeliac disease. Thus, we consider that relative LC, whose biopsy shows decreased mucosal enzyme activity and a raised intraepithelial lymphocyte count with normal villous formation, probably has coeliac disease. Multiple small intestinal biopsies are being arranged to confirm the diagnosis.

In untreated coeliac patients there is no correlation between the presence of reticulin antibody in the serum and the clinical severity of the coeliac disease as indicated by faecal fat excretion. In this study, the levels of IgG were significantly higher in untreated reticulin-positive patients than in those without this antibody. This is in contrast to the findings of Brown et al (1973), who found no difference in the individual immunoglobulins in children with or without reticulin antibodies.

In the present study the reticulin antibody response as a screening test would have picked up 12 of the 14 previously undiagnosed coeliac patients among a group of 82 first-degree relatives of coeliac 
patients. Reticulin antibody is a more sensitive indicator of gluten-sensitive enteropathy than any other screening procedure, namely, physical examination, haemoglobin, serum iron or folate, in common use in the west of Ireland (Mylotte et al, 1974).

The incidence of false positives among 'normal relatives' of coeliac patients and controls is not significantly different. The frequency of positive reticulin antibodies in non-coeliac persons is sufficiently low to make the reticulin antibody test useful as a population screening procedure when deciding whom to biopsy.

The authors wish to thank Rosaleen Keane for her expert technical assistance in performing mucosal biopsy enzymatic assays, Dr Helen Grimes and her staff for performing routine biochemical assays, Professor J. D. Kennedy and Dr M. P. G. Little for reporting on histological sections, the physicians and surgeons of the Regional Hospital, Galway, for referring patients for study, and the Wellcome Trust, the Medical Research Council of Ireland, and the Western Health Board for their generous financial support.

\section{References}

Alarcón-Segovia, D., Herskovic, T., Wakin, K. G., Green, P. A., and Scudamore, H. H. (1964). Presence of circulating antibodies to gluten and milk fractions in patients with nontropical sprue. Amer. J. Med., 36, 485-499.

Alp, M. H., and Wright, R. (1971). Autoantibodies to reticulin in patients with idiopathic steatorrhoea, coeliac disease and Crohn's disease and their relation to immunoglobulins and dietary antibodies. Lancet, 2, 682-685.

Amman, A. J., and Hong, R. (1971). Unique antibodies to basement membrane in patients with selective IgA deficiency and coeliac disease. Lancet, 1, 1264-1266.

Asquith, P. (1974). Adult coeliac disease and malignancy. Irish med. J., 67, 417-420.

Austad, W. I., Cornes, J. S., Gough, K. R., McCarthy, C. F., and Read, A. E. (1967). Steatorrhoea and malignant lymphoma. Amer. J. dig. Dis., 12, 475-490.

Barry, R. E., and Read, A. E. (1973). Coeliac disease and malignancy. Quart. J. Med., 42, 665-675.

Brown I. L., Ferguson, A., Carswell, F., Horne, C. H. W., and MacSween, R. N. M. (1973). Autoantibodies in children with coeliac disease. Clin. exp. Immunol., 13, 373-382.

Dahlquist, A. (1968). Assay of intestinal disaccharidases. Analyt. Biochem., 22, 99-107.

von Essen, R., Savilahti, E., and Pelkonen, P. (1972). Reticulin antibody in children with malabsorption. Lancet, 1, 1157-1159.

Ferguson, A., and Carswell, F. (1972). Percipitins to dietary proteins in serum and upper intestinal secretions of coeliac children. Brit. med. J., 1, 75-77.

Ferguson, A., and Murray, D. (1971). Quantitation of intraepithelial lymphocytes in human jejunum. Gut, 12, 988-994.

Ferguson, R., Asquith, P., and Cooke, W. T. (1974). The jejunal cellular infiltrate in coeliac disease complicated by lymphoma. Gut, 15, 458-461.

Fry, L., Seah, P. P., McMinn, R. M. H., and Hoffbrand, A. V. (1972). Lymphocytic infiltration of epithelium in diagnosis of glutensensitive enteropathy. Brit. med. J., 3, 371-374.

Gough, K. R., Read, A. E., and Naish, J. M. (1962). Intestinal reticulosis as a complication of idiopathic steatorrhoea. Gut, 3, 232-239.

Harris, O. D., Cooke, W. T., Thompson, H., and Waterhouse, J. A. H. (1967). Malignancy in adult coeliac disease and idiopathic steatorrhoea. Amer. J. Med., 42, 899-912.

Holmes, G. K. T. Asquith, P., Stokes, P. L., and Cooke, W. T. (1974). Cellular infiltrate of jejunal biopsies in adult coeliac disease in relation to gluten withdrawal. Gut, 15, 278-283.

Kelly, M. H., and Hamilton, J. R. (1970). A micro-technique for the assay of intestinal alkaline phosphatase. Results in normal children and in children with celiac disease. Clin. Biochem., 3, 3343.

Kenrick, K. G., and Walker-Smith, J. A. (1970). Immunoglobulins and dietary protein antibodies in childhood coeliac disease. Gut, 11, 635-640.

Lowry, O. H., Rosebrough, N. J., Farr, A. L., and Randall, R. J. (1951). Protein measurement with the Folin phenol reagent. J. biol. Chem., 193, 265-275.

MacDonald, W. C., Dobbins, W. O., and Rubin, C. E. (1965). Studies of the familial nature of celiac sprue using biopsy of the small intestine. New Engl. J. Med., 272, 448-456.

McCarthy, C. F., Fraser, I. D., Evans, K. T., and Read, A. E. (1966). Lymphoreticular dysfunction in idiopathic steatorrhoea. Gut, 7, 140-146.

McNicholl, B. Egan-Mitchell, B., and Fottrell, P. F. (1974). Varying susceptibility to gluten in coeliac disease. In Coeliac Disease: Proceedings of the Second International Coeliac Symposium, edited by W. Th. J. M. Hekkens and A. S. Pena, pp. 413-419. Stenfert Kroese, Leiden.

Magalhaes, A. F. N., Peters, T. J., and Doe, W. F. (1974). Studies on the nature and significance of connective tissue antibodies in adult coeliac disease and Crohn's disease. Gut, 15, 284-288.

Mawhinney, H. (1973). MD Thesis, Queen's University, Belfast, pp. 98-103.

Montgomery, R. D., and Shearer, A. C. I. (1974). The cell population of the upper jejunal mucosa in tropical sprue and post infective malabsorption. Gut, 15, 387-391.

Mylotte, M., Egan-Mitchell, B., Fottrell, P. F., McNicholl, B., and McCarthy, C. F. (1972). Familial coeliac disease. (Abstr.), Quart. J. Med., 41, 527-528.

Mylotte, M., Egan-Mitchell, B., McCarthy, C. F., and McNicholl, B. (1973). The incidence of coeliac disease in the West of Ireland. Brit. Med. J., 1, 703-705.

Mylotte, M., Egan-Mitchell, B., Fottrell, P. F., McNicholl, B., and McCarthy, C. F. (1974). Family studies in coeliac disease. Quart. J. Med., 43, 359-369.

Nusslé, D., Frei, J., Bozic, C., and Gautier, E. (1970). Proximal and distal alterations of the intestinal mucosa in coeliac disease: relation to the degree of malabsorption. In Coeliac Disease, edited by C. C. Booth and R. H. Dowling, pp. 45-53. Churchill Livingstone, Edinburgh.

Rizzetto, M., and Doniach, D. (1973). Types of 'reticulin' antibodies detected in human sera by immunofluorescence. J. clin. Path., 26, 841-851.

Robinson, D. C., Watson, A. J., Wyatt, E. H., Marks, J. M., and Roberts, D. F. (1971). Incidence of small-intestinal mucosal abnormalities and clinical coeliac disease in the relatives of children with coeliac disease. Gut, 12, 789-793.

Seah, P. P., Fry, L., Hoffbrand, A. V., and Holborow, E. J. (1971a). Tissue antibodies in dermatitis herpetiformis and adult coeliac disease. Lancet, 1, 834-836.

Seah, P. P., Fry, L. Rossiter, M. A., Hoffbrand, A. V., and Holborow, E. J. (1971b). Anti-reticulin antibodies in childhood coeliac disease. Lancet, 2, 681-682.

Seah, P. P., Fry, L., Holborow, E. J., Rossiter, M. A., Doe, W. F., Magalhaes, A. F., and Hoff brand, A. V. (1973). Antireticulin antibody, incidence and diagnostic significance. Gut, 14, 311-315.

Shipman, R. T., Williams, A. L., Kay, R., and Townley, R. R. W. (1973). Quoted in Clin. Gastroent., 2, 549 and 551. In Clinics in Gastroenterology, 2, 3, edited by R. G. McConnell. Saunders, London.

Stokes, P. L., Asquith, P., and Cooke, W. T. (1973). Genetics of coeliac disease. Clin. Gastroent., 2, 547-556.

Stokes, P. L., and Holmes, G. K. T. (1974). Malignancy. Clin. Gastroent., 3, 159-170. 